\title{
Transport Accessibility in a Suburban Zone and Its Influence on the Local Real Estate Market: A Case Study of the Olsztyn Functional Urban Area (Poland)
}

\author{
Agnieszka Szczepańska (D)
}

check for updates

Citation: Szczepańska, A. Transport Accessibility in a Suburban Zone and Its Influence on the Local Real Estate Market: A Case Study of the Olsztyn Functional Urban Area (Poland). Land 2021, 10, 465. https://doi.org/ 10.3390/land10050465

Academic Editor: Luca Salvati

Received: 11 April 2021

Accepted: 23 April 2021

Published: 29 April 2021

Publisher's Note: MDPI stays neutral with regard to jurisdictional claims in published maps and institutional affiliations.

Copyright: (C) 2021 by the author. Licensee MDPI, Basel, Switzerland. This article is an open access article distributed under the terms and conditions of the Creative Commons Attribution (CC BY) license (https:/ / creativecommons.org/licenses/by/ $4.0 /)$.
Department of Socio-Economic Geography, Institute of Spatial Management and Geography, Faculty of Geoengineering, University of Warmia and Mazury in Olsztyn, Prawocheńskiego 15, 10-724 Olsztyn, Poland; aszczep@uwm.edu.pl

\begin{abstract}
The development of real estate markets in the vicinity of cities is linked with suburbanization processes. The migration of the population to suburban areas contributes to the growth of the residential property market (houses, apartments and construction plots). To minimize commuting costs, property buyers opt for locations that are situated close to the urban core. This article analyzes construction plots on the local real estate market in the Olsztyn Functional Urban Area, in terms of their temporal accessibility and demographic changes. Spatial variations in population distribution were analyzed with the use of the Gini index and geostatistical interpolation techniques. Spearman's rank correlation coefficient was calculated to determine the relationships between the analyzed variables. The study revealed differences in the spatial distribution of the population and real estate transactions as well as strong correlations between average transaction price, number of transactions, commuting time and population. The highest number of transactions were observed in cadastral districts situated in the direct vicinity of Olsztyn's administrative boundaries and the major transportation routes due to their high temporal accessibility.
\end{abstract}

Keywords: transport accessibility; real estate market; population; concentration

\section{Introduction}

Suburbanization leads to the sprawl of residential areas in the vicinity of an urban core. This process affects the morphology of suburban areas, their functions and the development of suburban infrastructure. The migration of the population to suburban areas contributes to the formation of settlement subsystems around the city center. This process stimulates the growth of local real estate markets, in particular, the number of transactions involving construction plots. City residents migrating to suburbs base their purchasing decisions on a property's location relative to the urban core. Real estate in the city is swapped for much cheaper and more attractively located properties in a suburban zone. Lower prices and a cleaner environment are the main reasons why city dwellers seek property in suburban areas.

Commuting time strongly influences the decisions made by the buyers of suburban property [1,2]. In suburban areas, the share of space intended for residential, commercial and industrial purposes are increasing [3]. The urbanization of rural areas surrounding the city is closely linked with distance to the functional urban core [3] and the availability of transport infrastructure [4-7]. Feedback mechanisms between accessibility, land-use and travel behavior were observed [8]. Buyers search for property in areas with well-developed road networks. Dwellers who migrate to suburbs continue to maintain close links with the city, and commuting entails high costs [9,10]. The cost and time of travel to work [11,12], school or commercial outlets is lower in suburban areas that are easily accessed from the urban core [13,14]. Daily commuting is the consequence of population shift from cities to suburban areas, which increases the demand for locations $[15,16]$ with well-developed transport infrastructure [17-19]. Property buyers hope to maximize benefits and minimize 
costs by searching for a compromise between the price and quality of property and its distance from the urban core. They strive to minimize both the physical and temporal distance between the place of residence and the city. The above increases the demand for locations characterized by shorter commuting time and lower transportation costs [20-22].

Commuting increases road traffic because passenger vehicles are the main mode of transport for suburban residents [23] since public transport options are limited and do not always cover local transport needs. Daily commuting costs are a significant item in household budgets, but they are compensated by lower property prices in suburban areas. It has been said that the expenditures associated with daily travel are a different form of mortgage carrying costs. Time is also a factor that has specific economic value because it is a limited resource; therefore, commuting time, rather than distance, is the key determinant of transport accessibility [24]. Research studies conducted at various levels have also demonstrated that transport accessibility can influence property prices [25-27]. The balance between transport accessibility and the remaining attributes of real estate in rural areas (specific locations) have also been examined in suburban areas in Poland [28,29]. Therefore, the intensity and the spatial extent of suburbanization are inversely proportional to the demand for real estate, and the demand for and supply of construction plots influences real estate prices and the development of real estate markets in the suburban zone [30]. The demand for construction plots shifts the boundaries of the urban real estate market outwards [31-33]. The intensity and trends of suburbanization are reflected on the suburban real estate market and the accompanying changes in land use, population structure and investments. These processes are mutually interdependent, and they contribute to the formation of the urbanization cycle (Figure 1).

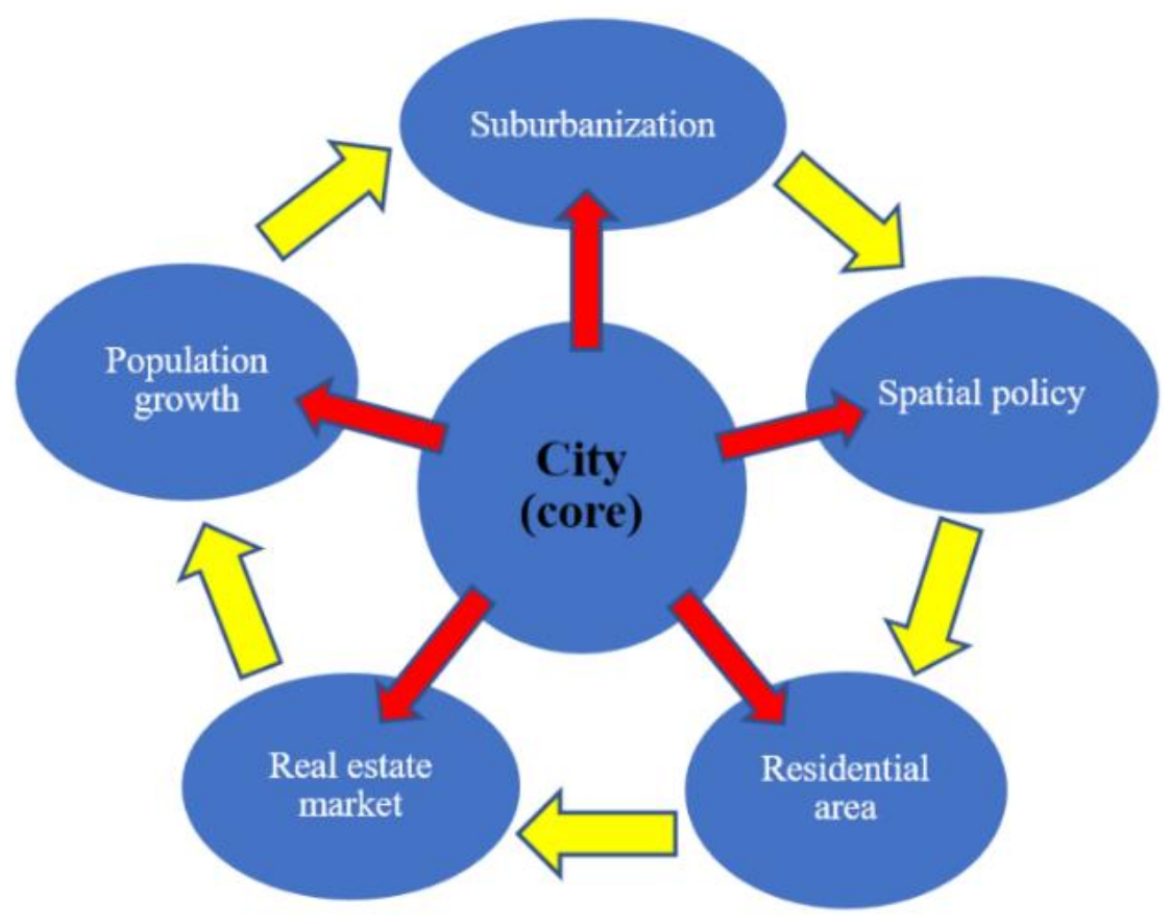

Figure 1. The urbanization cycle. Source: [34].

The suburban real estate market is characterized by a high and growing number of transactions involving vacant land. The supply of and the demand for construction plots continues to increase, which increases property prices. The prices of residential property are influenced by numerous factors, but the prices of suburban property are determined mainly by the size of the town or village and its distance from the urban core. Land prices generally decrease with an increase in distance from the city [35-37], and the development of transport infrastructure drives urbanization and home prices [36,38-40]. This observation is consistent with the new urban economics concept, which postulates 
that the prices of residential property are influenced by distance from the city core (land prices decrease as the distance from the city increases).

Urban expansion is thus directly linked to the growth of the real estate market, and real estate prices are determined by numerous factors. Deng et al. [41] proposed the following formula to illustrate differences in urban expansion as a function of economic and geophysical factors:

Urban land area $=\mathrm{f}$ (income growth, demographic shifts, agricultural land value, transportation costs, changes in the structure of the economy, other location and geophysical variables)

These factors also influence the real estate market [42,43]. Transportation costs are one of such factors, and the changes in and the reach of functional urban areas are linked with the real estate market $[41,44]$. Therefore, temporal accessibility is one of the key factors that influence the choice of location and, consequently, the real estate market. Transportation costs, expressed both in time and money, significantly influence property value, and buyers strive to maximize benefits in the process of selecting the optimal location.

Similar processes and interactions are observed in the former Soviet bloc countries of Central-Eastern Europe. In the socialist era, cities were relatively homogeneous functional urban areas with clearly delimited centers, whereas suburban zones were not well developed. The political transformations of 1989 led to changes inside urban areas and their surroundings. Central planning was abandoned, and free market principles were introduced. These changes affected the housing market and introduced a new urban order, which gave rise to capitalist-type cities and urban sprawl. Growing levels of social and economic inequality induced new types of migration, including urban to suburban migration. Rural areas surrounding cities developed rapidly, and suburbanization became one of the most spectacular phenomena in the former Soviet bloc countries [45,46]: Estonia [47], Slovakia [48], Bulgaria [49], Romania [50] and the Czech Republic [51].

The introduction of ground rents and property rights as a result of political and economic transformations also triggered suburbanization processes in Poland [52-55], and real estate purchases in suburban areas increased due to growing affluence. The growth of real estate markets in suburban areas accelerated after the political transformations of 1989 [56,57], especially around big cities [58-60]. Since 1990, spatial planning policies and progressing suburbanization have led to significant changes in land-use structure (increase in residential area), infrastructure development, population and the number of transactions involving residential property. The type and scope of these changes have varied intensity and territorial scope, and they are largely determined by an urban area's status in the hierarchy of cities. The migration of the urban population to suburbia proceeded most rapidly in the largest cities, followed by medium-sized towns.

Suburbanization is a relatively new phenomenon in Poland, and it largely follows the trends observed in other countries. However, this process has certain unique characteristics in Poland [53,61]:

- it proceeds far more rapidly than in Western Europe,

- $\quad$ it is not effectively controlled by planning authorities,

- technical and social infrastructure in suburban areas are extremely inadequate,

- rural municipalities in suburban areas are formally independent of cities and are not a part of their administrative structure,

- the distance from the urban core plays a key role in property purchase decisions, and buyers tend to opt for larger construction plots,

- new homes are built along the existing transport routes,

- the original structure of suburban villages is completely transformed by new development, mostly single-family homes with typical urban design,

- large-scale residential developers have a limited interest in suburban areas, and

- $\quad$ suburban development is homogeneous and linked with the family life cycle. 
In Poland, most suburbanization processes are uncontrolled due to the passive stance of urban planning authorities and the relaxation of planning regulations. The above leads to spatial chaos, low economic effectiveness of new settlements and a shortage of vital services. The low spatial accessibility of suburban settlements increases development costs and public expenditures, including transport costs and the time needed to introduce complementary services that are essential for the functioning of territorial and social systems [62-64]. Transport accessibility to the urban core is determined by the daily demand for commuter services, and accessibility tends to decrease over distance from the city [65-67]. Transport accessibility significantly impacts purchase decisions and consumer behavior on property markets. The choices made by real estate buyers can be analyzed based on the information about the location and prices of traded property.

Olsztyn, the city in north-eastern Poland, has a rapidly developing suburban zone. This medium-sized city is the capital of the Warmińsko-Mazurskie Voivodeship, and it occupies a high rank in the hierarchy of Polish cities. The following research hypotheses were tested in the study:

- $\quad$ Suburbanization processes affect the local real estate market. Analyses of local property markets can generate valuable information about the territorial reach and dynamics of suburbanization.

- Distinctive features of Polish suburbanization processes are observed in the vicinity of Olsztyn. Distance from the urban core and commuting time play a key role in property purchase decisions; new homes are built along transport routes, which influences the prices of construction plots; single-family homes are the predominant type of new construction in suburban areas, which affects the prices and availability of land sold for residential development.

The aim of the study was to determine whether suburbanization processes in the vicinity of Olsztyn conform to trends that are characteristic of Poland, and to define the territorial reach and dynamics of suburbanization based on local market data. The areas most affected by suburbanization were identified, and the demand for and supply of construction plots were analyzed. In this article, the number of transactions involving construction plots on the suburban real estate market was analyzed based on commuting time and distance from the city core. The observed processes were linked with demographic changes, which are the key determinant of suburbanization. The links between temporal accessibility expressed by commuting time, the prices on the local real estate market and demographic processes were identified, and their spatial distribution was described based on data for 2007-2018.

\section{Materials and Methods}

\subsection{Study Area}

The studied area was the Olsztyn Functional Urban Area (FUA) composed of six municipalities that are directly adjacent to the city: Barczewo, Dywity, Gietrzwałd, Jonkowo, Purda and Stawiguda (Figure 2). Olsztyn is the capital city of the Warminsko-Mazurskie Voivodeship in north-eastern Poland and is an important regional hub. Olsztyn had a population of around 170,000 in 2018. The population of the suburban zone was estimated at 44,000 .

The residents of the Olsztyn FUA were surveyed in 2014, and the results were published in a report entitled "Spatial relations in public and private transport in the Olsztyn Functional Urban Area in the context of urban mobility" [68]. The study revealed that private cars were the preferred mode of transportation for suburban residents commuting to the city. Passenger cars are widely available [69,70], and they are the main means of transport [71] between suburban zones and the urban core. The surveyed respondents relied on private means of transport to commute to work, school and commercial outlets, and the choice of private cars was dictated mainly by shorter commuting time. As a result, the number of passenger cars registered in the county of Olsztyn increased from 48,013 in 2009 to 71,549 in 2018 (data from the Central Statistical Office). The study also revealed 
considerable differences in access to residential areas in the Olsztyn FUA, and temporal accessibility was highest in towns and villages located along the main transportation routes. Nearly a third of the towns and villages in the Olsztyn FUA were characterized by low transport accessibility.
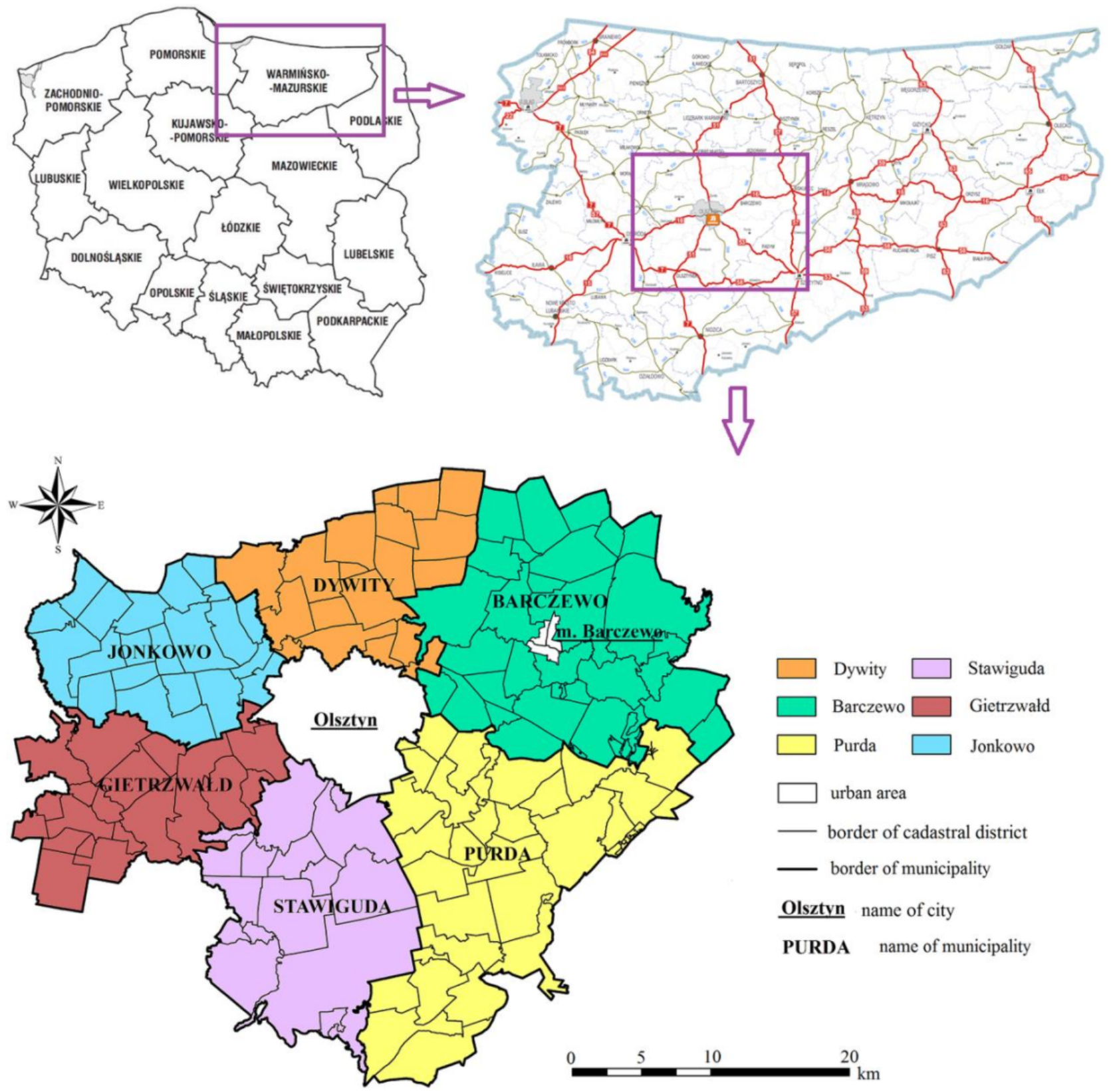

Figure 2. Study area. Source: own elaboration.

Public transport services include bus lines operated by the municipalities (public bus lines reach only 11 out of 138 towns and villages, some of them only on a seasonal basis) and, to a limited extent, by railway lines. Bus lines are also operated by commercial carriers, but they only target the most highly populated towns and villages. The vast majority of suburban settlements have to rely on private means of transport which are characterized by the shortest commuting time and the highest travel comfort [72-74].

Integrated Territorial Projects (ITP) are one of the priority goals of the Strategy of the Olsztyn FUA, and they were initiated to improve the quality of transportation in that area. This development tool was introduced to implement territorial strategies in an integrated manner. The initiative enables local authorities to launch joint projects that are co-financed 
by the European Regional Development Fund and the Social Fund as part of the European Union's Regional Operational Programs.

\subsection{Methods}

Temporal accessibility is evaluated based on physical distance as well as travel time. Travel time in the existing road network of the Olsztyn FUA was determined with the use of the Google Maps application. Travel time was measured from the administrative center of Olsztyn (City Hall) to different locations (cadastral districts) in the suburban zone. The analysis was carried out for travel by passenger car on the same date and at the same time (Wednesday, averaged result for 5 and 19 September 2018, 6 p.m.). Commuting times were interpolated for the entire studied area. The spatial distribution of the unit prices of construction plots in 2007 and 2018 were interpolated in the next stage of the analysis.

The information about the prices of construction plots (Register of Real Estate Prices and Values) and their location (base maps in the Land and Building Register, data in dxf format for cadastral plots in Barczewo, Dywity, Gietrzwałd, Jonkowo, Purda and Stawiguda) were obtained from the County Center for Geodetic and Cartographic Documentation in Olsztyn.

In both cases (temporal accessibility and prices of construction plots), data were interpolated by kriging. This method is widely applied to interpolate the spatial distribution of data, in particular, prices [75-81]. Kriging is the main method for estimating continuous surfaces based on the measured points. The estimated value is calculated as the weighted average of $n$ measured points surrounding the estimated location. The kriging estimate (Formula (2)) is a realization of the random function $Z(s i)$ :

$$
Z^{*}\left(S_{o}\right)=\sum_{i=1}^{n} w_{i} Z\left(s_{i}\right)
$$

where $w_{i}$ denotes kriging weights, $Z^{*}\left(S_{0}\right)$ is the value at the interpolated point and $Z\left(S_{0}\right)$ is the value at the measured point.

Kriging is used to define the range and anisotropy of spatial correlations and to identify directional changes in spatial phenomena. Data were interpolated in ArcGIS software.

Spearman's rank correlation coefficient was calculated (Formula (3)) to describe the relationships between the number of transactions, average unit price, population and temporal accessibility. This ranking method is not highly sensitive to outliers.

$$
r_{s}=\frac{\frac{1}{6}\left(n^{3}-n\right)-\left(\sum_{i=1}^{n} d_{i}^{2}\right)-T_{z}-T_{y}}{\sqrt{\left(\frac{1}{6}\left(n^{3}-n\right)-2 T_{z}\right)\left(\frac{1}{6}\left(n^{3}-n\right)-2 T_{y}\right)}},
$$

where $r_{s}$ is Spearman's rank correlation coefficient, $d_{i}=R_{x_{i}}-R_{y_{i}}$ is the difference between the ith rank of variable $x$ and the $i$ th rank of variable $y, T_{z}$ and $T_{y}$ are the coefficients of tied ranks expressed as $T=\frac{1}{12} \sum_{j}\left(t_{j}^{3}-t_{j}\right)$ and $t_{j}$ is the number of observations with the $j$ th rank in the analyzed dataset.

Spearman's rank correlation coefficient was calculated, and scatter plots were generated in the Statistica program.

The Gini index, which measures concentration relative to uniform distribution in the overall set of values of the analyzed variable, was calculated to determine the inequality in the spatial distribution of the analyzed variables (Formula (4)).

$$
G_{i}=\frac{\sum_{i=1}^{n}(2 i-n-1) y_{i}}{n^{2} \bar{y}}
$$

where $G_{i}$ is the Gini index, $y_{i}$ is the value of the ith observation, $\bar{y}$ is the average value of all observations and $n$ is the total number of observations.

The Gini index was computed with the use of an online calculator available at [82]. 


\section{Results}

The construction of the Olsztyn ring road commenced during the analyzed period. Planning and design work began in 2005. The contracts for the construction of the first and second segment of the ring road were signed in 2015 and 2016, and the first segment was commissioned for use in December 2018. The construction of the Olsztyn-Olsztynek express road intersecting Stawiguda municipality took place in the same period, and it improved transport accessibility in Stawiguda which already had the most highly developed road infrastructure in the Olsztyn suburban zone. The ring road considerably improved transport conditions, in particular, by diverting heavy transit traffic away from downtown Olsztyn. Despite the above, the ring road had only a minor impact on the temporal accessibility of suburban settlements.

The travel time for the entire studied area (between downtown Olsztyn and all settlements in the Olsztyn urban functional area) was interpolated based on the calculated commuting times (Figure 3). The location of the construction plots sold between 2007 and 2018 were marked on the temporal accessibility map.

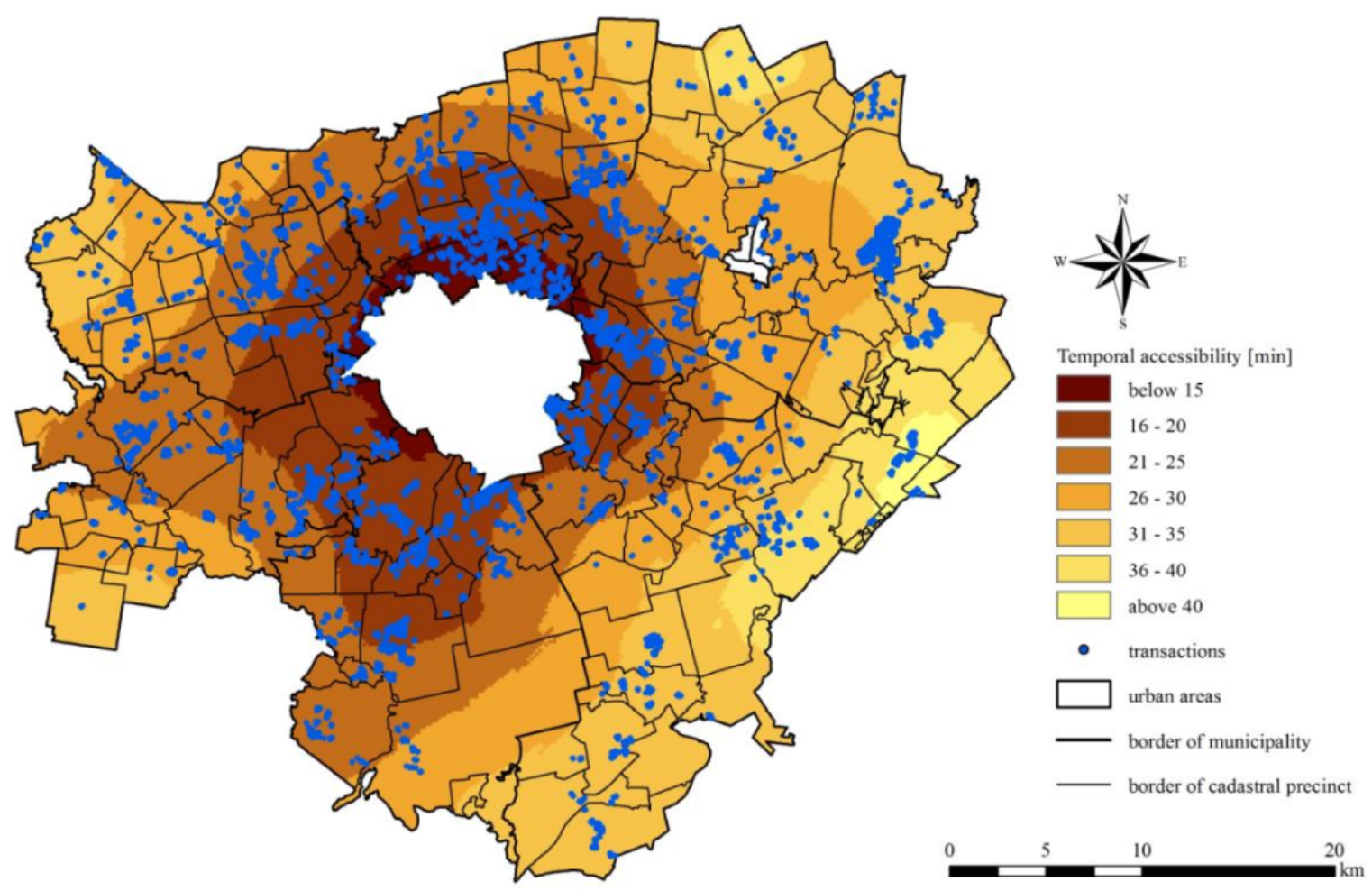

Figure 3. Temporal accessibility and spatial distribution of transactions in the suburban zone of Olsztyn in 2007-2018. Source: own elaboration.

The spatial distribution of temporal accessibility revealed local variations, mostly in the southern and south-western parts of the Olsztyn FUA. These areas are intersected by major roads, including the road linking Olsztyn with the Polish capital of Warsaw. The number of transactions change with an increase in travel time. These results indicate that the density of settlements decreased exponentially with an increase in distance from the urban core, which is consistent with urban development theories [83]. The map in Figure 2 also illustrates the extent to which the quality of transportation routes influences temporal accessibility. The number of transactions concluded in the cadastral districts of the Olsztyn FUA are presented in Figure 4. 


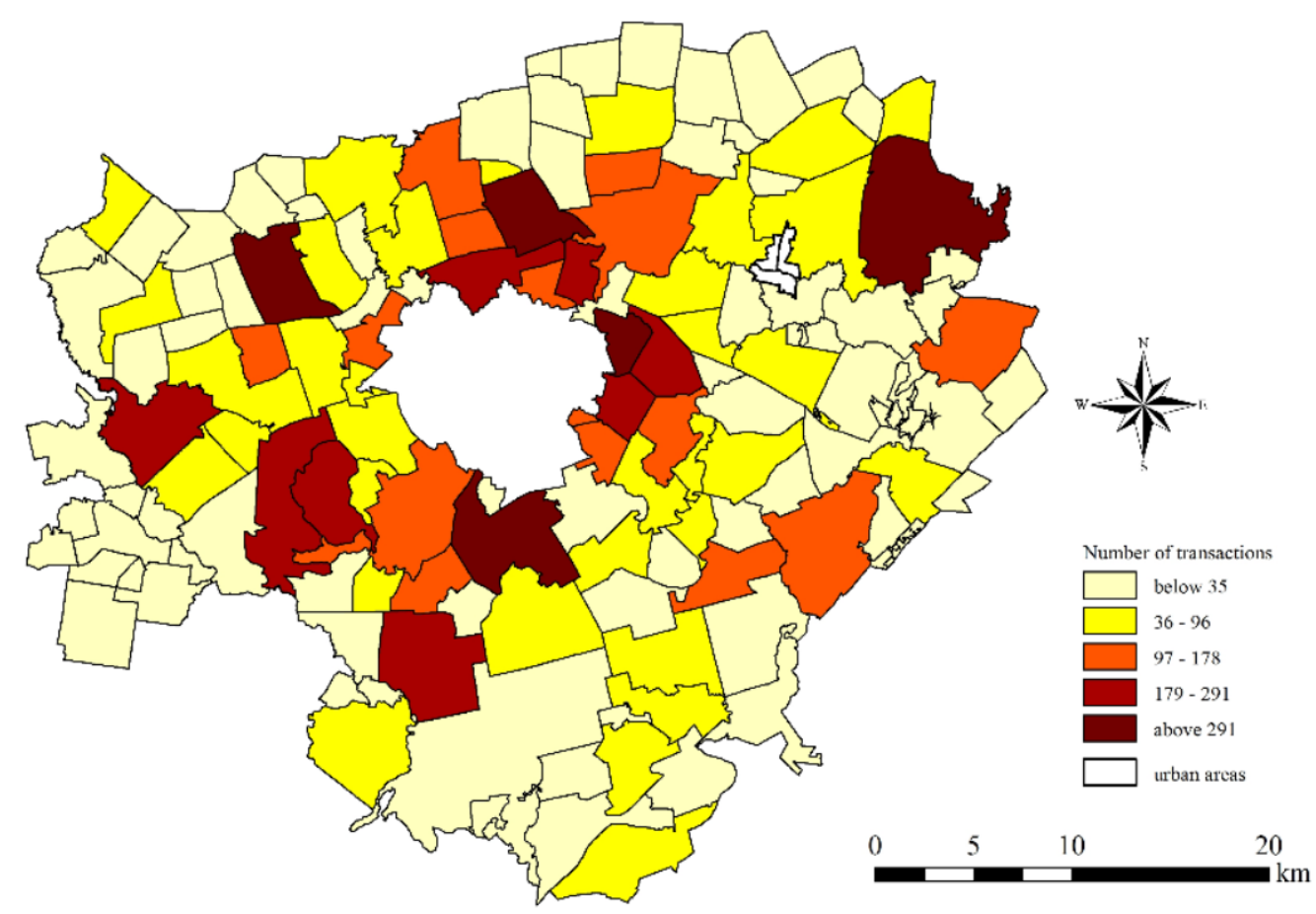

Figure 4. Number of transactions concluded in the cadastral districts of the Olsztyn FUA between 2007 and 2018.

The distance to the urban core and the number of real estate transactions are bound by an inversely proportional relationship. The number of transactions decreases with an increase in distance from Olsztyn's administrative boundaries (Figures 2 and 3). The highest number of transactions were concluded in cadastral districts situated in the direct proximity of Olsztyn and along the express road to Warsaw (south-west of Olsztyn). The outlier in the north-eastern part of the studied area is a cadastral district which remains under the influence of another city, Mragowo.

The distribution of the unit prices of construction plots was also analyzed to determine the spatial pattern of real estate transactions on the local market. This is an important consideration because the choice of location is linked with prices, and prices influence decision-making [84]. The spatial distribution of the unit prices of construction plots was interpolated (Figure $5 \mathrm{a}, \mathrm{b}$ ) to identify trends in the development of the suburban zone and prime locations (based on prices).

The results of the interpolation point to an increase in the prices of construction plots between 2007 and 2018 and reveals prime locations with the highest temporal accessibility. The prices of construction plots were highest along the administrative boundaries of Olsztyn and in Stawiguda municipality, followed by the municipality of Gietrzwałd. These areas were characterized by the highest temporal accessibility.

The choices made by real estate buyers influence land use. New residential areas are created, which leads to changes in population [85]. Temporal accessibility induces demographic changes, and differences in commuting time influence population density. In the studied area, changes in population were strongly linked with access to transport infrastructure. As demonstrated in Figure 6, population decreased with an increase in commuting time. More people settle in areas with better accessibility. 
a)
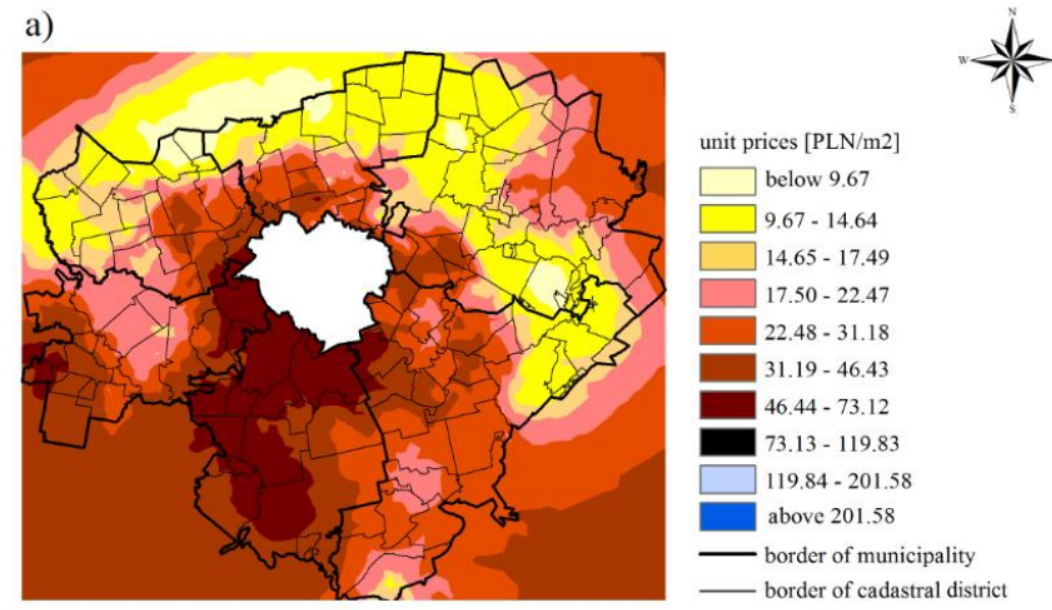

b)

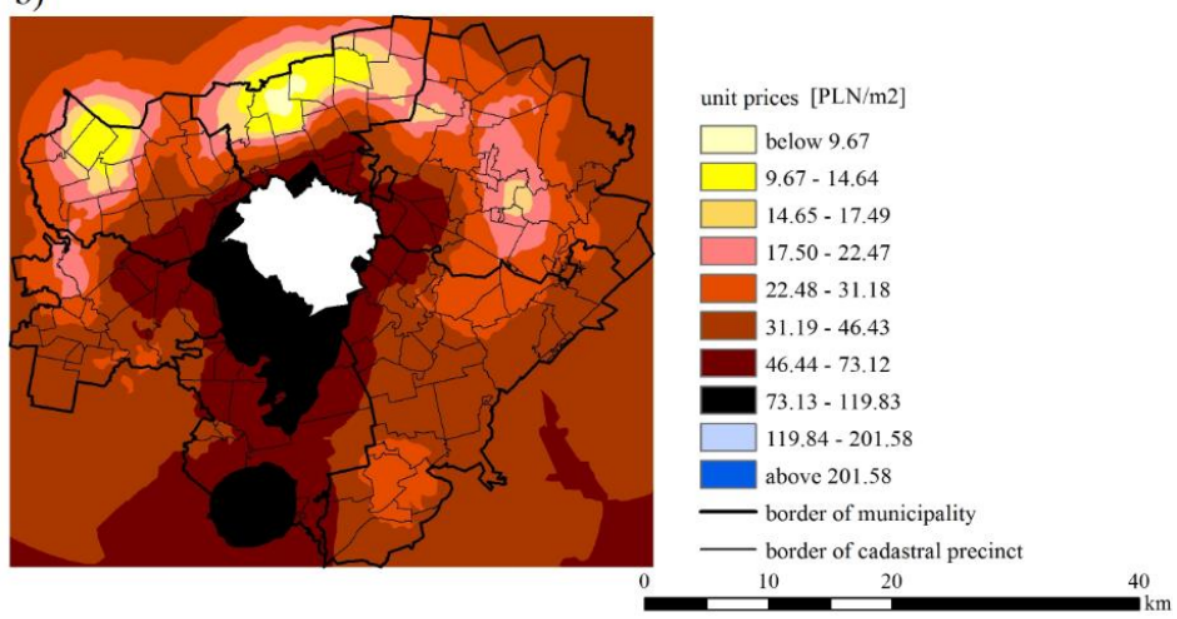

Figure 5. Interpolation of the unit prices of construction plots in the Olsztyn FUA in 2007 (a) and 2018 (b). Source: Own elaboration based on the Register of Real Estate Prices and Values kept by the County Center for Geodetic Documentation and Maps in Olsztyn.

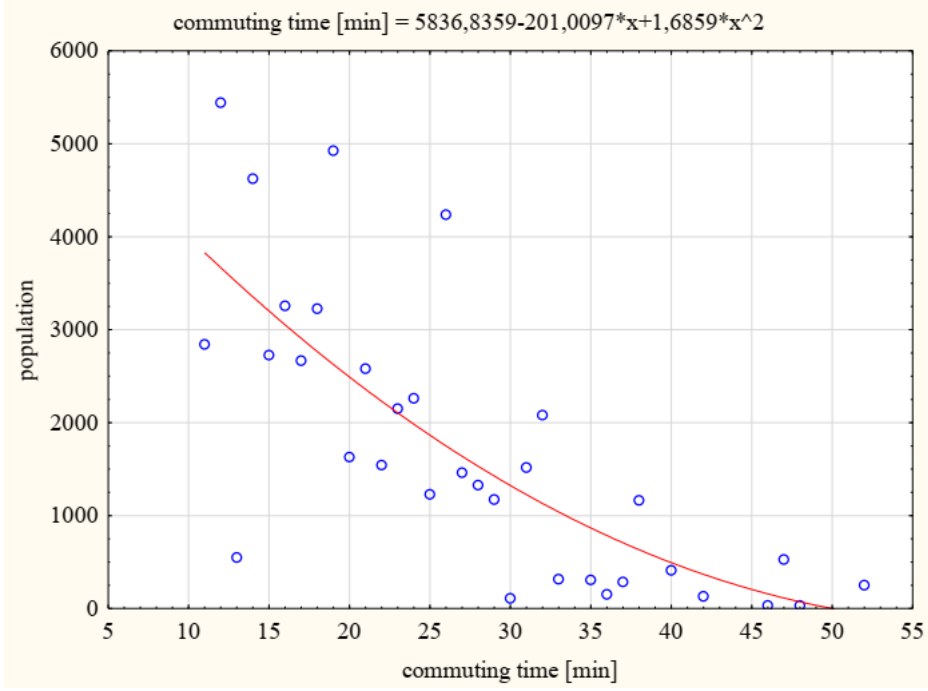

Figure 6. Relationship between population and commuting time in 2018. Source: own elaboration.

Similar population trends were noted in cadastral districts. Relative population growth was highest in the vicinity of Olsztyn and in districts with the highest temporal 
accessibility (Figure 7). At the same time, the population of the city of Olsztyn decreased by about $2 \%$.

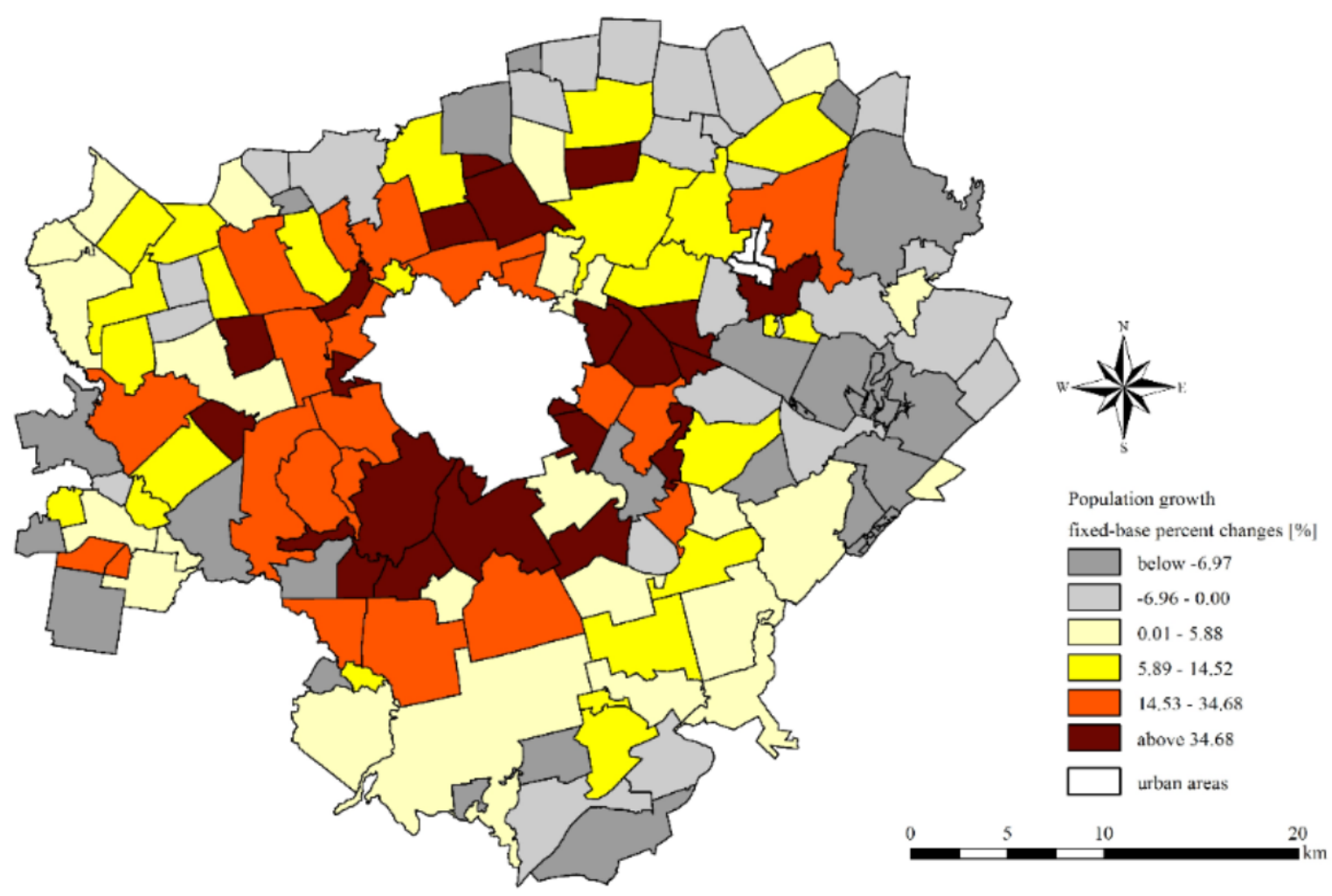

Figure 7. Relative population growth in the Olsztyn FUA in 2007-2018. Source: own elaboration.

The distribution of transactions, population and unit prices determines the homogeneity of the processes observed in the suburban zone. Therefore, the Gini index was calculated for the above variables (Table 1 ).

Table 1. Gini index of variables in the suburban zone of Olsztyn.

\begin{tabular}{|c|c|c|c|c|c|c|c|c|c|}
\hline \multirow{2}{*}{$\begin{array}{c}\text { Gini } \\
\text { Index }\end{array}$} & \multicolumn{2}{|c|}{ Population } & \multirow{2}{*}{$\begin{array}{c}\begin{array}{c}\text { Population } \\
\text { Growth }\end{array} \\
2017-2018\end{array}$} & \multicolumn{2}{|c|}{ Average Price } & \multirow{2}{*}{$\begin{array}{c}\text { Number of } \\
\text { Transactions }\end{array}$} & \multirow{2}{*}{$\begin{array}{c}\begin{array}{c}\text { Number of } \\
\text { Transactions }\end{array} \\
2018\end{array}$} & \multirow{2}{*}{$\begin{array}{c}\text { Number of } \\
\text { Transactions }\end{array}$} & \multirow{2}{*}{$\begin{array}{c}\begin{array}{c}\text { Commuting } \\
\text { Time }\end{array} \\
2018\end{array}$} \\
\hline & 2007 & 2018 & & 2007 & 2018 & & & & \\
\hline $\begin{array}{l}\text { Olsztyn } \\
\text { FUA }\end{array}$ & 0.4934 & 0.5372 & 0.8233 & 0.4298 & 0.4364 & 0.5853 & 0.6110 & 0.6274 & 0.4584 \\
\hline
\end{tabular}

Source: own elaboration.

The calculated values of the Gini index revealed growing inequality in population distribution in the Olsztyn FUA (decrease in population uniformity). The number of transactions and the average unit prices in cadastral districts were also characterized by high values of the Gini index, which points to variations in the spatial distribution of these variables. The values of the Gini index also revealed considerable differences in the temporal accessibility of the analyzed districts, which suggests strong links between these variables.

The relationships between the analyzed variables were evaluated by calculating Spearman's rank correlation coefficients (Table 2). 
Table 2. Spearman's rank correlation coefficients for the analyzed variables.

\begin{tabular}{|c|c|c|c|c|c|c|c|c|c|}
\hline \multirow[b]{2}{*}{ Variable } & \multicolumn{9}{|c|}{ Spearman's Rank Correlation Coefficients, $p<0.05$} \\
\hline & $\begin{array}{c}\text { Travel Time } \\
2018\end{array}$ & $\begin{array}{c}\text { Population Growth } \\
\text { 2007-2018 }\end{array}$ & $\begin{array}{l}\text { Population } \\
2007\end{array}$ & $\begin{array}{l}\text { Population } \\
2018\end{array}$ & $\begin{array}{c}\text { Number of } \\
\text { Transactions } \\
2007-2018\end{array}$ & $\begin{array}{c}\text { Number of } \\
\text { Transactions } \\
2007\end{array}$ & $\begin{array}{c}\text { Number of } \\
\text { Transactions } \\
2018\end{array}$ & $\begin{array}{c}\text { Average Price } \\
2007\end{array}$ & $\begin{array}{c}\text { Average Price } \\
2018\end{array}$ \\
\hline Travel time 2018 & 1.0000 & -0.6683 & $x$ & -0.5230 & -0.5388 & $x$ & -0.3851 & $x$ & -0.5799 \\
\hline $\begin{array}{c}\text { Population growth } \\
\text { 2007-2018 }\end{array}$ & $\mathrm{x}$ & 1.0000 & 0.3553 & 0.5950 & 0.5897 & 0.6117 & 0.2574 & 0.2842 & 0.5616 \\
\hline Population 2007 & $\mathrm{x}$ & $\mathrm{x}$ & 1.0000 & 0.8860 & 0,6468 & 0.5650 & 0.3687 & 0.1706 & 0.1411 \\
\hline Population 2018 & $\mathrm{x}$ & $\mathrm{x}$ & $\mathrm{x}$ & 1.0000 & 0.7236 & 0.6663 & 0.3961 & 0.2425 & 0.3118 \\
\hline $\begin{array}{l}\text { Number of } \\
\text { transactions } \\
2007-2018\end{array}$ & $\mathrm{x}$ & $\mathrm{x}$ & $x$ & $x$ & 1.0000 & 0.2825 & 0.2575 & 0.2496 & 0.3750 \\
\hline $\begin{array}{c}\text { Number of } \\
\text { transactions } 2007\end{array}$ & $\mathrm{x}$ & $\mathrm{x}$ & $\mathrm{x}$ & $\mathrm{x}$ & $\mathrm{x}$ & 1.0000 & 0.4435 & 0.2241 & 0.3157 \\
\hline $\begin{array}{c}\text { Number of } \\
\text { transactions } 2018\end{array}$ & $\mathrm{x}$ & $\mathrm{x}$ & $x$ & $\mathrm{x}$ & $\mathrm{x}$ & $\mathrm{x}$ & 1.0000 & 0.1412 & 0.1714 \\
\hline Average price 2018 & $x$ & $x$ & $x$ & $x$ & $x$ & $x$ & $x$ & $x$ & 1.0000 \\
\hline
\end{tabular}


The calculated values of the Spearman's rank correlation coefficient point to moderate and strong correlations between the analyzed variables $(>0.5000)$. The strongest relationships were noted between the number of transactions and population, between travel time and population growth, and between travel time and average price. Travel time was negatively correlated with the remaining variables.

The results validate the assumption that the local real estate market was directly linked to urbanization processes expressed by demographic data. The analyses also confirmed the presence of cause-and-effect relationships between the evaluated variables.

The correlations between commuting time vs. the number of transactions and average unit prices were illustrated in scatter plots (Figure 8a,b). The scatter plots also present the influence of temporal accessibility on the local real estate market.

a)

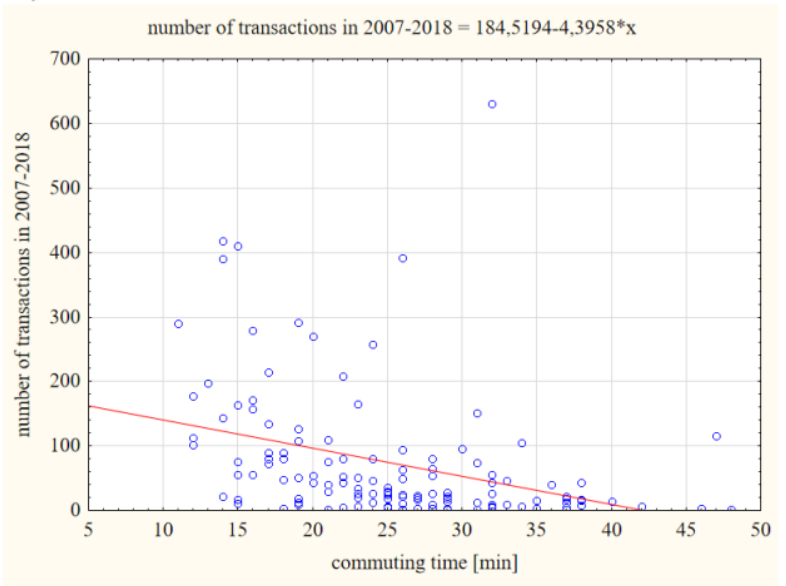

b)

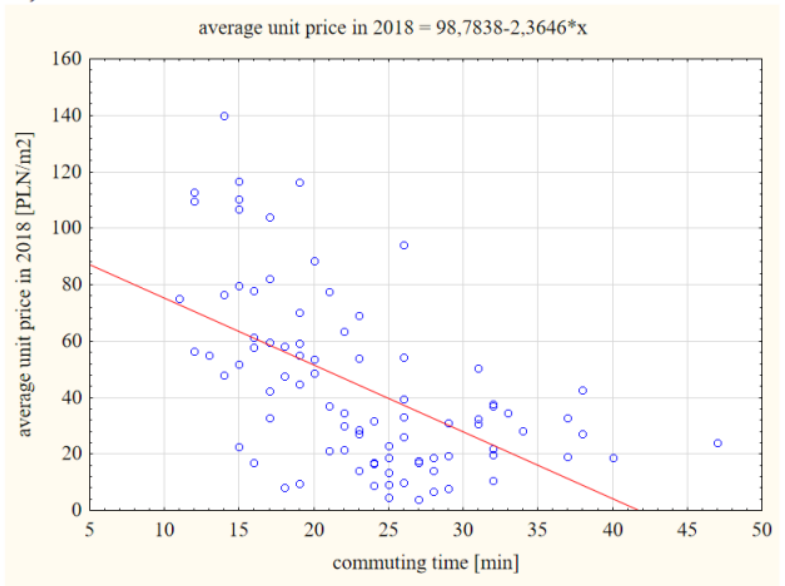

Figure 8. Correlations between (a) commuting time and the number of transactions, (b) commuting time and average unit prices. Source: own elaboration.

\section{Discussion}

The study demonstrated that suburbanization proceeds rapidly in the areas surrounding Olsztyn, but the spatial distribution of suburban settlements is irregular and characterized by significant local variations. The present findings validate the hypothesis that suburbanization influences the number of transactions on local real estate markets, and that transaction volumes reflect the dynamics and territorial reach of suburbanization. The results of this study also indicate that access to the transportation network significantly influences local real estate markets in suburban areas. Similar observations were made by other authors, who demonstrated that transport accessibility influences prices and transactions on the real estate market $[86,87]$. The correlations noted in this and other studies were similar, regardless of the size of the urban core $[88,89]$.

Transport accessibility also influences the choice of locations on the real estate market and, consequently, population growth [90]. This feedback mechanism stimulates the growth of the real estate market. Buyers have a greater interest in residential areas with well-developed technical infrastructure and public facilities. Most areas that meet the above requirements are located in the direct vicinity of cities, and their greatest advantage is the proximity of the urban core. However, suburban areas are often deficient in social infrastructure, and many of them feature only basic retail outlets. Local residents have to commute to Olsztyn to satisfy other life needs. In contrast, rural municipalities situated further away from Olsztyn rely on local potential and attributes to develop local infrastructure. These municipalities have schools, healthcare facilities, local government offices and shops. As a result, basic life needs are met locally, and the residents do not have to travel to Olsztyn.

Herding behavior can also play an important role in real estate choices. Herding behaviors disrupt rational decision making because individuals follow other people and 
imitate group behaviors. Buyers who search for suburban property often follow trends without realizing that the most popular locations are characterized by high levels of urbanization and do not differ considerably from cities (in particular, locations adjacent to city limits). In an attempt to escape the hustle and bustle of urban life, many buyers ultimately pay a high price for locations that resemble the city.

The above factors lead to spatial disruptions. The analyzed variables were not evenly distributed and contributed to disproportions between the evaluated cadastral districts. A comparison of the Gini index for the first and last year of the analyzed period revealed growing differences in population distribution, the number of transactions and average prices, which contributed to disproportions between cadastral districts. Due to similar transport accessibility, cadastral districts adjacent to Olsztyn are characterized by the highest population, the highest number of property transactions and the highest prices of construction plots. However, an analysis of the areas located south-east of Olsztyn revealed considerable deficiencies in transport planning policies both at the local (municipal) and supralocal level. These observations are validated by the spatial distribution of the analyzed variables in the maps presented in Section 3. High values of the Gini index point to uneven distribution, which suggests that the Olsztyn FUA is characterized by considerable fragmentation of the analyzed phenomena. The above generates spatial chaos, and it compromises effective land management. The intensity and spatial concentration of the investigated processes were determined by distance from the city core and the proximity of the main transportation routes, which influences transport accessibility of the studied cadastral districts. Land prices, the number of real estate transactions and changes in the population growth rate decrease with an increase in distance from the urban core. Similar trends were reported by other authors [83,91].

\section{Conclusions}

Olsztyn is an example of a city where transport accessibility has an influence on the development of the suburban area and the local real estate market. Similar processes are observed in all large cities in Poland, particularly in areas situated in the vicinity of regional capitals and along the main transport corridors, for example, Białystok [31], TorunBydgoszcz [92,93], Kraków [94] and Gdańsk-Gdynia-Sopot [95], because suburban dwellers rely mainly on private transport, whereas other forms of transport play a secondary role $[63,96]$. The results of this study validate the observations made by Śleszyński [97], who noted that accessibility expressed in monetary terms does not discount the improvement in temporal accessibility resulting from the construction of new roads.

This article presents the results of the first stage of research. The eastern, southern and western fragments of the Olsztyn ring road were commissioned for use in July 2019. The ring road and the accompanying access roads will considerably improve transport accessibility in the Olsztyn FUA. Faster travel and the higher throughput of traffic entering the city will increase temporal accessibility between cadastral districts in the evaluated suburban zone. The new road system will facilitate transport between the urban core and suburban districts, and it will provide suburban commuters with easier access to the city. These changes could stimulate new residential development projects in the suburban zone. Similar observations were made by other authors [98,99], including in Polish cities [100,101].

The new ring road plays a very important role in the 2016 Strategy of the Olsztyn Functional Urban Area. The new route will facilitate transit between Olsztyn and suburban districts, and the residents of the Olsztyn FUA will no longer have to cross the city center when traveling between suburban municipalities. The ring road will eliminate traffic bottlenecks, increase the throughput of the existing transportation routes and make travel between Olsztyn and suburban municipalities more comfortable. These changes could affect local real estate markets in the suburban zone. In the second stage of the research, the real estate markets in the Olsztyn FUA will be evaluated two years after the launch of the ring road. 
The added value of the present research is that data were analyzed at the level of cadastral districts, whereas most studies of the type are conducted at the level of municipalities. The adopted approach supports more accurate assessments of the observed changes, which is particularly important in medium-sized (and smaller) cities and towns that exert a weaker effect on the surrounding areas. In contrast, analyses conducted at the level of municipalities produce generalized and less precise observations.

Funding: This research received no external funding.

Conflicts of Interest: The authors declare no conflict of interest. The funders had no role in the design of the study; in the collection, analyses, or interpretation of data; in the writing of the manuscript; or in the decision to publish the results.

\section{References}

1. Zhang, W.; Guhathakurta, S. Residential Location Choice in the Era of Shared Autonomous Vehicles. J. Plan. Educ. Res. 2018, 41, 0739456X18776062. [CrossRef]

2. Filion, P. Enduring Features of the North American Suburb: Built Form, Automobile Orientation, Suburban Culture and Political Mobilization. Urban Plan. 2018, 3, 4-14. [CrossRef]

3. Tokarczyk-Dorociak, K.; Kazak, J.; Szewranski, S. The Impact of a Large City on Land Use in Suburban Area: The Case of Wrocław (Poland). J. Ecol. Eng. 2018, 19, 89-98. [CrossRef]

4. Aljoufie, M.; Brussel, M.; Zuidgeest, M.; Van Maarseveen, M. Urban growth and transport infrastructure interaction in Jeddah between 1980 and 2007. Int. J. Appl. Earth Obs. Geoinf. 2013, 21, 493-505. [CrossRef]

5. Murphy, E. Urban spatial location advantage: The dual of the transportation problem and its implications for land-use and transport planning. Transp. Res. Part A Policy Pract. 2012, 46, 91-101. [CrossRef]

6. García-Palomares, J.C. Urban sprawl and travel to work: The case of the metropolitan area of Madrid. J. Transp. Geogr. 2010, 18, 197-213. [CrossRef]

7. Maat, C. Built Environment and Car Travel: Analyses of Interdependencies; IOS Press BV: Amsterdam, The Netherlands, 2009; Volume 29.

8. Geurs, K.T.; van Wee, B. Accessibility evaluation of land-use and transport strategies: Review and research directions. J. Transp. Geogr. 2004, 12, 127-140. [CrossRef]

9. Jones, P.; Lucas, K. The social consequences of transport decision-making: Clarifying concepts, synthesising knowledge and assessing implications. J. Transp. Geogr. 2012, 21, 4-16. [CrossRef]

10. Vega, A.; Reynolds-Feighan, A. A methodological framework for the study of residential location and travel-to-work mode choice under central and suburban employment destination patterns. Transp. Res. Part A Policy Pract. 2009, 43, 401-419. [CrossRef]

11. Zolnik, E.J. The Effect of Sprawl on Private-Vehicle Commuting Outcomes. Environ. Plan. A Econ. Space 2011, 43, 1875-1893. [CrossRef]

12. Karst, T.; Van Eck, J.R.R. Evaluation of Accessibility Impacts of Land-Use Scenarios: The Implications of Job Competition, Land-Use, and Infrastructure Developments for the Netherlands. Environ. Plan. B Plan. Des. 2003, 30, 69-87. [CrossRef]

13. Lee, Y.; Washington, S.; Frank, L.D. Examination of relationships between urban form, household activities, and time allocation in the Atlanta Metropolitan Region. Transp. Res. Part A Policy Pract. 2009, 43, 360-373. [CrossRef]

14. Crane, R. The Influence of Urban Form on Travel: An Interpretive Review. J. Plan. Lit. 2000, 15, 3-23. [CrossRef]

15. Delclòs-Alió, X.; Miralles-Guasch, C. Suburban travelers pressed for time: Exploring the temporal implications of metropolitan commuting in Barcelona. J. Transp. Geogr. 2017, 65, 165-174. [CrossRef]

16. Kortum, K.; Paleti, R.; Bhat, C.R.; Pendyala, R.M. Joint Model of Residential Relocation Choice and Underlying Causal Factors. Transp. Res. Rec. J. Transp. Res. Board 2012, 2303, 28-37. [CrossRef]

17. Dubé, J.; Thériault, M.; Rosiers, F.D. Commuter rail accessibility and house values: The case of the Montreal South Shore, Canada, 1992-2009. Transp. Res. Part A Policy Pract. 2013, 54, 49-66. [CrossRef]

18. Jaume, M.T. Sub-Centres and mobility patterns: A study on Social and Environmental Costs due to Commuting in the Barcelona Metropolitan Region. In Proceedings of the 59th Annual North American Meetings of the Regional Science Association International, Ottawa, ON, Canada, 7-10 November 2012.

19. Poelmans, L.; Van Rompaey, A. Complexity and performance of urban expansion models. Comput. Environ. Urban Syst. 2010, 34, 17-27. [CrossRef]

20. Szczepanska, A.; Senetra, A. Migrations of city dwellers to suburban areas-The example of the city of Olsztyn. Bull. Geogr. Socio-Econ. Ser. 2012, 18, 117-124. [CrossRef]

21. Nurlaela, S.; Curtis, C. Modeling Household Residential Location Choice and Travel Behavior and Its Relationship with Public Transport Accessibility. Procedia Soc. Behav. Sci. 2012, 54, 56-64. [CrossRef]

22. Molin, E.J.E.; Timmermans, H.J.P. Accessibility considerations in residential choice decisions: Accumulated evidence from the Benelux. In Proceedings of the 82nd Annual Meeting of the Transportation Research Boards, Washington, DC, USA, 12-16 January 2003. 
23. Maat, K.; Timmermans, H.J. Influence of the residential and work environment on car use in dual-earner households. Transp. Res. Part A Policy Pract. 2009, 43, 654-664. [CrossRef]

24. Rodrigue, J.P. The Geography of Transport. Systems; Routledge: New York, NY, USA, 2020.

25. Niu, F.; Wang, F.; Chen, M. Modelling urban spatial impacts of land-use/ transport policies. J. Geogr. Sci. 2019, $29,197-212$. [CrossRef]

26. Jun, M.J.; Kim, H.J. The effects of Seoul's suburban beltway on accessibility, residential development, and housing rents: A transport-land use simulation approach. Ann. Reg. Sci. 2016, 56, 565-589. [CrossRef]

27. Zhuge, C.; Shao, C.; Gao, J.; Dong, C.; Zhang, H. Agent-based joint model of residential location choice and real estate price for land use and transport model. Comput. Environ. Urban Syst. 2016, 57, 93-105. [CrossRef]

28. Więcław-Michniewska, J.; Czado, J. Rynek nieruchomości w podkrakowskich gminach na przykładzie działek budowlanych i rolnych. In Człowiek i Rolnictwo; Górka, Z., Zborowski, A., Eds.; Uniwersytet Jagielloński: Kraków, Poland, 2009 ; pp. $239-249$.

29. Hermann, B.; Świdurska, B. Analiza cen transakcyjnych nieruchomości zurbanizowanych w powiecie obornickim w kontekście przemian funkcjonalno-przestrzennych. Biul. Stow. Rzeczozn. Mająt. Woj. Wielkop. 2017, 47, 107-116.

30. Plantinga, A.J.; Lubowski, R.N.; Stavins, R.N. The effects of potential land development on agricultural land prices. J. Urban Econ. 2002, 52, 561-581. [CrossRef]

31. Harasimowicz, A. Procesy urbanizacji w strefie zewnętrznej Białegostoku. Optimum. Econ. Stud. 2019, 97, 125-150. [CrossRef]

32. Musiał-Malagó, M. Stan i kierunki rozwoju infrastruktury transportowej w Polsce. Zesz. Nauk. Uniw. Ekon. Krak. 2013, 914, 97-111.

33. Sýkora, L.; Bouzarovski, S. Multiple Transformations. Urban Stud. 2011, 49, 43-60. [CrossRef]

34. Szczepańska, A. Modelowanie Zmian Przestrzennych Wywołanych Decyzjami Lokalizacyjnymi z Zastosowaniem Sieci Bayesa i Statystyk Morana na Przykładzie Strefy Podmiejskiej Olsztyna; Wydawnictwo Uniwersytetu Warmińsko-Mazurskiego w Olsztynie: Olsztyn, Poland, 2017.

35. Jacob, B.; McMillen, D. Border Effects in Suburban Land Use. Natl. Tax J. 2015, 68, 855-873. [CrossRef]

36. Zheng, S.; Kahn, M.E. Land and residential property markets in a booming economy: New evidence from Beijing. J. Urban Econ. 2008, 63, 743-757. [CrossRef]

37. Martínez, F.J.; Araya, C.A. A Note on Trip Benefits in Spatial Interaction Models. J. Reg. Sci. 2000, 40, 789-796. [CrossRef]

38. Rahadi, R.A.; Wiryono, S.K.; Koesrindartoto, D.P.; Syamwil, I.B. Factors influencing the price of housing in Indonesia. Int. J. Hous. Mark. Anal. 2015, 8, 169-188. [CrossRef]

39. Holcombe, R.G.; Williams, D.W. Urban Sprawl and Transportation Externalities. Rev. Reg. Stud. 2010, 40, 257-273. [CrossRef]

40. Colwell, P.F.; Munneke, H.J. The Structure of Urban Land Prices. J. Urban Econ. 1997, 41, 321-336. [CrossRef]

41. Deng, X.; Huang, J.; Rozelle, S.; Uchida, E. Growth, population and industrialization, and urban land expansion of China. J. Urban Econ. 2008, 63, 96-115. [CrossRef]

42. Kayzer, D.; Szczepański, P.; Zbierska, A.; Zydroń, A. Czynniki wpływające na wartość nieruchomości niezabudowanych przeznaczonych na cele budowlane. Stud. Pr. WNEiZ 2015, 42, 257-267. [CrossRef]

43. Gawron, H. Wpływ cech fizycznych działek na ceny gruntów budowlanych w aglomeracji miejskiej (na przykładzie aglomeracji poznańskiej). Stud. Mater. TNN 2012, 20, 47-57.

44. McGrath, D.T. More evidence on the spatial scale of cities. J. Urban Econ. 2005, 58, 1-10. [CrossRef]

45. Kovács, Z. Cities from state-socialism to global capitalism: An introduction. GeoJournal 1999, 49, 1-6. [CrossRef]

46. Stanilov, K.; Sýkora, L. Confronting Suburbanization; Wiley: Hoboken, NJ, USA, 2014; pp. 1-32.

47. Tammaru, T.; Kulu, H.; Kask, I. Urbanization, Suburbanization, and Counterurbanization in Estonia. Eurasian Geogr. Econ. 2004, 45, 212-229. [CrossRef]

48. Tóth, V. Urban development of Bratislava: Suburbanization in years 1995-2009. J. Geogr. 2012, 7, 115-126.

49. Slaev, A.D.; Nedović-Budić, Z.; Krunic, N.; Petric, J.; Daskalova, D. Suburbanization and sprawl in post-socialist Belgrade and Sofia. Eur. Plan. Stud. 2018, 26, 1389-1412. [CrossRef]

50. Dumitrache, L.; Zamfir, D.; Nae, M.M.; Simion, G.; Stoica, V. The Urban Nexus: Contradictions and Dilemmas of (Post)Communist (Sub)Urbanization in Romania. Hum. Geogr. J. Stud. Res. Hum. Geogr. 2016, 10, 38-50. [CrossRef]

51. Šašek, M.; Hlaváček, P.; Holub, J. Suburbanization processes of large cities in the Czech Republic in terms of migration. Bibl. Reg. 2019, 19, 209-225. [CrossRef]

52. Gałka, J.; Warych-Juras, A. Regionalne uwarunkowania suburbanizacji w Polsce. Stud. Miej. 2011, 3, $147-157$.

53. Heffner, K. Proces suburbanizacji a polityka miejska w Polsce. In Miasto-Region-Gospodarka w Badaniach Geograficznych; Marszał, T., Ed.; Wydawnictwo Uniwersytetu Łódzkiego: Łódź, Poland, 2016; pp. 75-110.

54. Gałka, J.; Warych-Juras, A. Suburbanization and migration in Polish metropolitan areas during political transition. Acta Geogr. Slov. 2018, 58. [CrossRef]

55. Szmytkie, R. Rozrost terytorialny dużych miast w Polsce. Prz. Geogr. 2020, 92, 499-520. [CrossRef]

56. Kałkowski, L. Polski rynek nieruchomościbilans otwarcia po wejściu Polski do Unii Europejskiej. Probl. Rozw. Miast 2007, 4, 12-45.

57. Gołąbeska, E. Współczesne trendy na rynku nieruchomości mieszkaniowych. Gospodarowanie przestrzenią w warunkach rozwoju zrównoważonego. In Gospodarowanie Przestrzenia w Warunkach Rozwoju Zrównoważonego; Broniewicz, E., Ed.; Oficyna Wydawnicza Politechniki Białostockiej: Białystok, Poland, 2017; pp. 85-106. 
58. Tanaś, J. Differentiation of Local Housing Markets in the Poznań Suburban Area. Real Estate Manag. Valuat. 2013, 21, 88-98. [CrossRef]

59. Trojanek, M. The local property markets for single-family housing in Poznan agglomeration in the period 1995-2010. Int. J. Acad. Res. 2013, 5, 211-219. [CrossRef]

60. Luchter, B. Wpływ transformacji gospodarczej na zmiany użytkowania ziemi w strefie zewnętrznej Krakowa. Zesz. Nauk. Akad. Ekon. Krak. 2003, 617, 177-191.

61. Wagner, W. 3. The Failure of Planning in a Fragmented Property Market: Poland's Model of Suburbanization. In Old Europe, New Suburbanization? University of Toronto Press: Toronto, ON, Canada, 2017; pp. 41-65.

62. Maćkiewicz, B.; Andrzejewski, A.; Kacprzak, E. Koszty bezładu przestrzennego dla rynku nieruchomości. Studia KPZK 2018, 182, 280-316.

63. Śleszyński, P. Społeczno-ekonomiczne skutki chaosu przestrzennego dla osadnictwa i struktury funkcjonalnej terenów. Studia KPZK 2018, 182, 29-80.

64. Zybała, A. Polityka przestrzenna i jej rezultaty w warunkach rosnącej złożoności jej problemów. Stud. z Polityki Publicz 2019, 22, 103-122. [CrossRef]

65. Śleszyński, P. Metodyczne problemy wyznaczania obszarów urbanizacji. Prz. Urban. 2015, 9, 60-61.

66. Rosik, P.; Pomianowski, W.; Kołoś, A.; Guzik, R.; Goliszek, S.; Stępniak, M.; Komornicki, T. Dostępność gmin transportem autobusowym. Pr. Kom. Geogr. Komun. PTG 2018, 21, 54-64. [CrossRef]

67. Borowska-Stefańska, M.; Wiśniewski, S. The use of network analysis in the process of delimitation as exemplifi ed by the administrative division of Poland. Geodesy Cartogr. 2017, 66, 155-170. [CrossRef]

68. UNIREGIO. Spatial Relations in Public and Private Transport in the Olsztyn Functional Urban Area in the Context of Urban Mobility; UNIREGIO: Kraków, Poland, 2014.

69. Ding, C.; Wang, D.; Liu, C.; Zhang, Y.; Yang, J. Exploring the influence of built environment on travel mode choice considering the mediating effects of car ownership and travel distance. Transp. Res. Part A Policy Pract. 2017, 100, 65-80. [CrossRef]

70. Maat, K.; Timmermans, H.J. A causal model relating urban form with daily travel distance through activity/travel decisions. Transp. Plan. Technol. 2009, 32, 115-134. [CrossRef]

71. Banet, K.; Rogala, S. Znaczenie współpracy miast i gmin w kreowaniu efektywnych systemów transportowych w odpowiedzi na zjawisko urban sprawl / Importance of cooperation between cities and communes in creating effective transportation systems as an answer to negative effects of urban sprawl. Pr. Nauk. Uniw. Ekon. Wroc. 2016, 443, 23-32. [CrossRef]

72. Mobility Plan of the Urban Functional Area until 2025; REFUNDA Sp. z o.o.: Wrocław, Poland, 2017.

73. Strategy for the Development of Public Transport in Olsztyn by 2027; Public Transport Consulting: Olsztyn, Poland, 2015.

74. Guzik, R.; Kołoś, A.; Biernacki, W.; Działek, J.; Gwosdz, K.; Kocaj, A.; Panecka, M.; Wiedermann, K. Relacje Przestrzenne Komunikacji Zbiorowej i Indywidualnej Miejskiego Obszaru Funkcjonalnego Olsztyna w kKntekście Mobilności Miejskiej. Raport Końcowy Wraz z Raportem Metodologicznym; UNIREGIO Centrum Studiów Regionalnych: Kraków, Poalnd, 2014.

75. Cellmer, R.; Trojanek, R. Towards Increasing Residential Market Transparency: Mapping Local Housing Prices and Dynamics. ISPRS Int. J. Geo-Inf. 2019, 9, 2. [CrossRef]

76. Calka, B. Estimating Residential Property Values on the Basis of Clustering and Geostatistics. Geoscience 2019, 9, 143. [CrossRef]

77. Kuntz, M.; Helbich, M. Geostatistical mapping of real estate prices: An empirical comparison of kriging and cokriging. Int. J. Geogr. Inf. Sci. 2014, 28, 1904-1921. [CrossRef]

78. Montero, J.; Larraz, B. Interpolation Methods for Geographical Data: Housing and Commercial Establishment Markets. J. Real Estate Res. 2011, 33, 233-244. [CrossRef]

79. Li, L.; Revesz, P. Interpolation methods for spatio-temporal geographic data. Comput. Environ. Urban Syst. 2004, $28,201-227$. [CrossRef]

80. Pagourtzi, E.; Assimakopoulos, V.; Hatzichristos, T.; French, N. Real estate appraisal: A review of valuation methods. J. Prop. Invest. Financ. 2003, 21, 383-401. [CrossRef]

81. McCluskey, W.J.; Deddis, W.G.; Lamont, I.G.; Borst, R.A. The application of surface generated interpolation models for the prediction of residential property values. J. Prop. Invest. Financ. 2000, 18, 162-176. [CrossRef]

82. Wessa, P. Concentration and Inequality (v1.0.1) in Free Statistics Software (v1.2.1), Office for Research Development and Education. 2016. Available online: http:/ / www.wessa.net/rwasp_concentration.wasp/. (accessed on 10 January 2021).

83. Cheng, J.; Masser, I. Urban growth pattern modeling: A case study of Wuhan city, PR China. Landsc. Urban Plan. 2003, 62, 199-217. [CrossRef]

84. Hurtubia, R.; Nguyen, M.H.; Glerum, A.; Bierlaire, M. Integrating psychometric indicators in latent class choice models. Transp. Res. Part A Policy Pract. 2014, 64, 135-146. [CrossRef]

85. Sener, I.N.; Pendyala, R.M.; Bhat, C.R. Accommodating spatial correlation across choice alternatives in discrete choice models: An application to modeling residential location choice behavior. J. Transp. Geogr. 2011, 19, 294-303. [CrossRef]

86. Osland, L.; Thorsen, I. Effects on Housing Prices of Urban Attraction and Labor-Market Accessibility. Environ. Plan. A Econ. Space 2008, 40, 2490-2509. [CrossRef]

87. Smersh, G.T.; Smith, M.T. Accessibility Changes and Urban House Price Appreciation: A Constrained Optimization Approach to Determining Distance Effects. J. Hous. Econ. 2000, 9, 187-196. [CrossRef] 
88. Siejka, M. Rozbudowa układu komunikacyjnego i jej wpływ na poziom cen i aktywność lokalnego rynku nieruchomości, na przykładzie obiektu Świniarsko w powiecie nowosadeckim. Infrastrukt. Ekol. Teren. Wiej. 2012, 2, 87-96.

89. Adair, A.; McGreal, S.; Smyth, A.; Cooper, J.; Ryley, T. House Prices and Accessibility: The Testing of Relationships within the Belfast Urban Area. Hous. Stud. 2000, 15, 699-716. [CrossRef]

90. Kotavaara, O.; Pukkinen, M.; Antikainen, H.; Rusanen, J. Role of Accessibility and Socio-Economic Variables in Modelling Population Change at Varying Scale. J. Geogr. Inf. Syst. 2014, 6, 386-403. [CrossRef]

91. Borzacchiello, M.T.; Nijkamp, P.; Koomen, E. Accessibility and urban development: A grid-based comparative statistical analysis of Dutch cities. Environ. Plan. B Plan. Des. 2010, 37, 148-169. [CrossRef]

92. Idczak, P.; Mrozik, K. Suburbanizacja w wybranych gminach wiejskich Bydgosko-Toruńskiego Obszaru Metropolitalnego. Stud. Pr. WNEiZ 2015, 42, 183-194. [CrossRef]

93. Piątkowski, K. Suburbanizacja jako wyzwanie dla rozwoju transportu w miejskim obszarze funkcjonalnym Bydgoszczy i Torunia. Rozw. Reg. Polit. Reg. 2019, 47, 141-154. [CrossRef]

94. Kurek, S.; Gałka, J.; Wójtowicz, M. Wpływ Suburbanizacji na Przemiany Wybranych Struktur Demograficznych i Powiązań FunkcjonalnoPrzestrzennych w Krakowskim Obszarze Metropolitalnym; Wydawnictwa Instytutu Geografii Uniwersytetu Pedagogicznego: Krakowie, Poland, 2015.

95. Masik, G. Suburbanizacja demograficzna i przestrzenna na Obszarze Metropolitalnym Gdańsk-Gdynia-Sopot: Demographic and spatial suburbanization in the Gdańsk-Gdynia-Sopot Metropolitan Area. Stud. Obsz. Wiej. 2018, 50, 155-170. [CrossRef]

96. Palak, M. Nowe Oblicza Przedmieść. Socjologiczne Studium Suburbanizacji w Polsce na Przykładzie Rzeszowa; Wydawnictwo Uniwersytetu Rzeszowskiego: Rzeszów, Poland, 2016.

97. Śleszyński, P. Dostępność ekonomiczna miast wojewódzkich w świetle kosztów dojazdu samochodem osobowym. Pr. Kom. Geogr. Komun. PTG 2017, 20, 7-18. [CrossRef]

98. Thomas, T.; Tutert, B. Route choice behavior in a radial structured urban network: Do people choose the orbital or the route through the city center? J. Transp. Geogr. 2015, 48, 85-95. [CrossRef]

99. Boarnet, M.G.; Chalermpong, S. New highways, house prices, and Urban development: A case study of toll roads in orange county, Ca. Hous. Policy Debate 2001, 12, 575-605. [CrossRef]

100. Kudłacz, M. Zewnątrzmiejska dostępność komunikacyjna w kontekście budowania atrakcyjności lokalizacyjnej metropolii w Polsce na przykładzie województwa małopolskiego. Zesz. Nauk. Uniw. Èkon. Krak. 2014, 935, 59-77. [CrossRef]

101. Rudnicki, A. Zrównoważona mobilność a rozwój przestrzenny miasta. Czas. Tech. Archit. 2010, 107, 57-74. 